\section{Moscow and} Bonn unite on environment

\section{Munich}

WEST Germany hopes "soon" to sign a broad agreement with the Soviet Union on the protection of the environment, according to the West German Environment Ministry last week. The announcement was made at the culmination of five days of talks with Soviet officials in Bonn.

The two-year pact will cover the prevention of air, water and land pollution as well as the prevention of accidents harmful to the environment. In addition, scientific and industrial exchanges between the two countries will also be outlined. The details of the agreement will be released only when it has finally been signed.

The environmental pact is just one indication of a thaw in relations between the two countries. West German cabinet ministers, including Research and Technology Minister Heinz Riesenhuber, are scurrying to set up appointments in Moscow in April, even before West German President Richard von Weizsäcker pays a newly scheduled visit there in May.

Riesenhuber is expected to sign an agreement on the peaceful uses of nuclear energy which has been on ice since late last year. The Soviets cancelled a visit by Riesenhuber to Moscow, planned for December, because of remarks made by German Chancellor Helmut Kohl in November, comparing Soviet leader Mikhail Gorbachev with Hitler's propaganda minister during the war, Josef Goebbels.

Two other agreements, on medical and agricultural research, are also expected to be signed by the two sides within the next few months.

The new pact with the Soviet Union may help to give the parallel negotiations with East Germany a stimulus, according to a source in the Environment Ministry. A high West German official, Wolfgang Schäuuble, returned on Friday from talks with East German leader Erich Honecker in East Berlin, saying that significant progress had been made on East-West German relations. The two-day meeting may have included a decision to sign (finally) a scientific agreement between the two German states which has been under negotiation since 1973. But Schäuuble refused to discuss the details of the talks, which also dealt with the invitation of Honecker to visit West Berlin on 30 April for the opening of the 750th anniversary celebration.

Steven Dickman

\title{
AZT given the green light for clinical treatment of AIDS
}

\section{Washington}

THE US Food and Drug Administration (FDA) announced on 20 March the approval of the first drug developed to combat AIDS (acquired immune deficiency syndrome). The drug zidovudine, commonly known as azidothymidine (AZT), will be marketed by Burroughs Wellcome under the trade name Retrovir.

AZT passed through human trials and cleared the FDA in 22 months, under an accelerated review process set up to speed the approval of breakthrough drugs. To receive AZT treatment now, AIDS patients must be striken with Pneumocystis carinii pneumonia or exhibit a CD4 (T4) lymphocyte count of less than 200. Patients with less severe AIDS and ARC (AIDS-related complex) indications may receive $A Z T$ once adequate supplies are assured.

Until production can meet demand for the drug to treat the approximately 14,000 AIDS cases and 40,000 advanced ARC cases now known in the United States, Burroughs Wellcome has set up a Retrovir control centre in Washington, DC to serve as a clearing house for applications submitted by physicians for individual AIDS patients. The centre will authorize shipment of the drug based on the type and severity of the patient's symptoms.

AZT disrupts the lifecycle of the AIDS virus by blocking the action of the enzyme reverse transcriptase (see Nature 325, 773; 1987). Although not a cure for AIDS, AZT improves the short-term survival of AIDS patients. But it does not come without side-effects, such as severe anaemia, and its long-term effects are unknown.

According to Burroughs Wellcome, treating one AIDS patient with AZT will cost about $\$ 8,000-10,000$ (US) a year. Representative Henry A. Waxman (Democrat, California) has asked the House Budget Committee for $\$ 60$ million in 1988 to help needy AIDS patients shoulder this financial burden. He has also appealed to the Appropriations Committee for emergency funding for those who cannot afford the drug this year.

Carroll Ezzell

\section{Inquiry cleared Gagarin of pilot error}

\section{London}

YURI Gagarin, the first man in space, who died in a training flight in March 1968, has finally been cleared of suspicion of pilot error and/or being at the controls of an aircraft while drunk. Although no such posthumous accusations were ever brought openly against Gagarin, and he remained officially a member of the Soviet space pantheon, the findings of the official inquiry into his fatal crash were never made public. This inevitably produced rumours about the causes of the accident. According to Valentina Tereshkova, the first woman cosmonaut, in the mid-1960s, the Soviet Union was planning a space mission to be led by Gagarin. No such mission materialized, fuelling speculation that Gagarin was out of favour.

Last week, however, Pravda belatedly published an account of the official inquiry into Gagarin's last flight, signed by Professor S. Belotserkovskii, winner of a state prize for his work in space science, and cosmonaut Aleksei Leonov. They concentrate on two main issues: the "aviation technology" of the aircraft and a "complex of questions" including pilot readiness, flight plan and adherence to safety regulations.

The commission established that all onboard systems operated faultlessly up to the very end. There was no evidence of fatigue in any of the components recovered nor of on-board fire or explosion. The engine was operating until impact, the electrical system and oxygen supply were working correctly, and the pilot's radio was on. Neither Gagarin nor his co-pilot Vladimir Seregin tried to eject.

Evidence from fellow-cosmonauts, who attended the pre-flight briefings with him on 26 and 27 March, and from doctors who analysed the tape-recordings of his final flight, indicated that Gagarin's behaviour and voice patterns revealed no unusual stress.

What, then, went wrong? According to the flight plan, the aircraft should have been making a turn from $70^{\circ}$ to $320^{\circ}$ while gradually descending between two layers of almost continuous cloud. Instead, it suddenly went into a near-vertical dive. Possible explanations are suggested: an "unexpected obstacle" (another aircraft, an aerosonde balloon, or possibly a flock of birds); encountering the slipstream of another aircraft; or hitting a rising vertical airstream could increase the angle of attack sufficiently to produce a stall. Whatever the cause, Gagarin and Seregin made a determined effort to fight their way out of the crisis. On the basis of the flight data and additional evidence of the trajectory, including the ground and tree-tops at the impact site, it appears that they almost succeeded. It has taken nineteen years and three changes of leadership for the Soviet people to be permitted to know this.

Vera Rich 